\title{
Translocation of 'Candidatus Liberibacter solanacearum', the Zebra Chip Pathogen, in Potato and Tomato
}

\author{
Julien Levy, Aravind Ravindran, Dennis Gross, Cecilia Tamborindeguy, and Elizabeth Pierson
}

First and fifth authors: Department of Horticultural Sciences, second and third authors: Department of Plant Pathology and Microbiology, and fourth author: Department of Entomology, Texas A\&M University, College Station 77843.

Accepted for publication 22 June 2011.

\section{ABSTRACT}

Levy, J., Ravindran, A., Gross, D., Tambrindeguy, C., and Pierson, E. 2011. Translocation of 'Candidatus Liberibacter solanacearum', the Zebra Chip pathogen, in potato and tomato. Phytopathology 101:1285-1291.

Zebra Chip disease is a serious threat to potato production. The pathogen, the phloem-limited bacterium 'Candidatus Liberibacter solanacearum,' is vectored by the potato and tomato psyllid Bactericerca cockerelli to potato and tomato. Patterns of pathogen translocation through phloem in potato and tomato plants were examined to determine whether rate or direction of translocation vary by host species or potato cultivars. Two insects were given a 7-day inoculation access period on a single leaf. Weekly, leaves from upper-, middle-, and lower-tier branches were tested for the presence of ' $\mathrm{Ca}$. L. solanacearum' by polymerase chain reaction (PCR). In tomato and potato, 'Ca. L. solanacearum' was detected 2 to 3 weeks after infestation, most frequently in upper- and middle-tier leaves. In potato, the pathogen was detected in leaves on a second, noninfested stem when the stems remained joined via the tuber. Although rates of pathogen movement were similar among potato cultivars, symptoms developed earlier in more susceptible cultivars. Quantitative PCR indicated that bacterial titers were frequently low in tomato and potato samples ( $<20$ genome units per nanogram of DNA). Results establish that, for improved detection, samples should include newly developing leaves and consider that, under low insect pressure, the pathogen may be undetectable by PCR until 3 weeks after infestation.
Since the appearance and description of Zebra Chip disease (ZC) (also known as Zebra Complex disease) in Mexico in the 1990s and in the United States in 2000, this disease has caused important economic losses, especially in the potato chip industry (18). In potato, aboveground symptoms of ZC-infected plants include stunting, leaf curling, chlorosis, leaf purpling, leaf scorch, swollen internodes, and aerial tubers $(18,19)$. Tuber symptoms include darkening of the medullary rays, especially when potato tubers are fried for chips, rendering them unsuitable for chip production. The discoloration of chips led to the name Zebra Chip for the disease. The disease also causes reduced yield and premature plant death. The causative agent is a nonculturable, phloemlimited bacterium known as 'Candidatus Liberibacter solanacearum' (also known as ' $C a$. L. psyllaurous'). It was identified based on its association with symptomatic plants and the production of ZC symptoms in asymptomatic plants following transmission by the potato and tomato psyllid vector, Bactericera cockerelli (Sulc.), or grafting $(3,5,18,19)$. To date, little is known about how 'Ca. L. solanacearum' causes ZC symptoms or the importance of pathogen translocation in host phloem during disease development. The pathogen can be transmitted by the potato and tomato psyllid to other solanaceous crops, including tomato and pepper, where aerial symptoms similar to ZC can be observed $(1,5,10)$.

Currently, no potato cultivars have been reported as resistant to ZC. Without disease resistance, ZC control depends largely on early detection and control of bacterialiferous insects. Current detection methods for ' $\mathrm{Ca}$. L. solanacearum' in plants rely pri-

Corresponding author: E. Pierson; E-mail address: eapierson@tamu.edu

* The $e$-Xtra logo stands for "electronic extra" and indicates that the online version contains one supplemental table and two supplemental figures.

doi:10.1094/PHYTO-04-11-0121

(c) 2011 The American Phytopathological Society marily on conventional polymerase chain reaction (cPCR) assays, with primer sets located in the 16S-ISR-23S rDNA region $(3,5,8,18,19)$. This has been somewhat unreliable in detecting the pathogen in symptomatic potato tissue $(8,19)$. For example, Wen et al. (19) demonstrated that detection in the same samples varied with primer and detection method used and was lowest in leaves and their midveins, intermediate in petioles and stems, and highest in stolons. Variability in pathogen detection in leaves of symptomatic plants may result from low pathogen titer, rates and patterns of pathogen translocation that result in uneven temporal and spatial pathogen distribution in plant tissues, or some undetermined methodological issue. Furthermore, discrepancies between the timing and pattern of pathogen movement and symptom development could contribute significantly to sampling and detection issues.

Understanding the direction and rate of translocation of ' $\mathrm{Ca}$. L. solanacearum' in the phloem of host plants is critical for determining when and where to sample plants in the field for early detection; helping to identify differences between susceptible and potentially tolerant cultivars in pathogen movement; and knowing when and in what tissues to look for differences in plant tissuemicrobe interactions that may be the key to understanding disease tolerance. In this study, we used two potato advanced selections that have been tentatively identified as ZC tolerant: NY138 and BTX1749-1W/Y $(13,14)$. These selections were based on evaluation of $>32,000$ individual tubers (fresh cut and chipped) for ZC tolerance as part of the Texas Potato Breeding Program, in which over 400 selections or named cultivars have been evaluated one or more times (http://potato.tamu.edu). We also employed two commercial cultivars that repeatedly have proven to be susceptible to ZC under field conditions in the same program: 'Atlantic' and 'Russet Norkotah'. Although it has not yet been firmly established that NY138 and BTX1749-1W/Y are ZC tolerant, we included them in this study to compare the rate of translocation of ' $\mathrm{Ca}$. L. solanacearum' in ZC-susceptible and potentially tolerant cultivars. We also included tomato plants because tomato can be a host for 
' $\mathrm{Ca}$. L. solanacearum' and there is growing concern regarding this disease in the tomato industry $(1,5)$.

In this study, we examined whether ' $C a$. L. solanacearum' spreads systemically in host plants via the phloem in a predictable manner and, if so, whether the direction or rate of translocation varies between host species (e.g., tomato versus tuber-forming potato) or between susceptible versus potentially tolerant potato cultivars.

\section{MATERIALS AND METHODS}

Insect material. Potato psyllids were maintained on tomato or potato plants in cages within growth chambers $\left(23 \pm 1{ }^{\circ} \mathrm{C}\right.$; photoperiod $16 \mathrm{~h}$ of light and $8 \mathrm{~h}$ of darkness). Two insects colonies were used, $\mathrm{C} 1$ ('Ca. L. solanacearum'-uninfected), with $0 \%$ of the insects harboring ' $\mathrm{Ca}$. L. solanacearum'; and $\mathrm{C} 2$ (' $\mathrm{Ca}$. L. solanacearum'-infected), with $\approx 70 \%$ of the insects harboring ' $C a$. L. solanacearum', as described previously (15).

Plant material. 'Cherry Red' tomato plants were grown from seed in 5-in. pots in Metromix 300 (Sun-Gro Horticulture). The plants were grown on light shelves with $24 \mathrm{~h}$ of light. Potato plants were grown from sprouting tubers in 2-gal. pots in Metromix 300 on light shelves with darkness-and-light cycles of 12 and $12 \mathrm{~h}$. Potato cultivars were classified as either susceptible (Russet Norkotah or Atlantic) or potentially tolerant (NY138 or BTX1749$1 \mathrm{~W} / \mathrm{Y})$. All potato lines were provided by the Texas Potato Breeding Program (Creighton Miller: http://potato.tamu.edu/). "Tolerant cultivars" were selections that had proven to exhibit ZC tolerance in multiple field trials $(13,14)$. Plants were started from tubers and, for each tuber, two stems were allowed to develop. As a control, the two stems from two additional plants (one Russet Norkotah and one NY1138) were physically separated at planting and allowed to develop in the same pot.

Plant inoculation. For tomato, $\approx 4$ weeks after planting, when the plants had developed multiple (six) tiers of branches, two adult psyllids were introduced within a small clip cage ("clip cage 1 inch internal diameter foam no thrips"; BioQuip, Rancho Dominguez, CA) attached to a single leaf on a middle-tier branch. There were two treatments based on the population of insects used to infest the plants: plants were infested with either psyllids from the ' $C a$. L. solanacearum'-infected C2 colony or the ' $C a$. L.'-uninfected C1 colony. The 'Ca. L. solanacearum'-uninfected $\mathrm{C} 1$ colony served as a symptom control to help discriminate symptoms of insect feeding from ZC. The insects were given a 7-day inoculation access period (IAP). Insects and progeny were then removed by excising the entire leaf and petiole hosting the insects. The infestation with psyllids from the ' $C a$. L. solanacearum'-infected C2 colony was repeated on five separate plants.

For potato, 4 to 5 weeks after planting, one shoot per plant was infested with two adult insects from the ' $\mathrm{Ca}$. L. solanacearum'infected C2 colony; the second stem was untreated. The insects were maintained on a single leaf within clip cages as described above. This protocol not only forced insects to feed on a leaf from a specific tier of branches but also forced insects to feed on both potentially tolerant and susceptible cultivars, removing insect preference from the comparison. The insects were given a 7-day IAP. The insects and progeny were then removed by excising the entire leaf and petiole hosting the insects. The 7-day IAP experiment was repeated three times with all four cultivars (total of 12 plants). In a separate experiment using three plants (one Atlantic, one Russet Norkotah, and one NY138), the insects were given a 21-day IAP to see if a longer feeding time would improve the possibility of detecting the pathogen.

Pathogen detection. At the end of the IAP, one leaf from an upper-, middle-, or lower-tier branch was sampled weekly for 8 weeks. DNA was extracted from the petiole tissue of each leaf. The presence of ' $\mathrm{Ca}$. L. solanacearum' was examined via cPCR using the specific primers Lso TX 16/23 (see below). Ampli- fication of potato $\beta$-tubulin was performed as an endogenous control for both tomato and potato assays. A tomato or potato plant known to have ZC and a plant with no exposure to insects were included as positive and negative controls, respectively.

For the DNA extraction, a sample of a leaf petiole with central vein tissue $\approx 1.5 \mathrm{~cm}$ long was excised from the selected leaves and DNA was extracted as describe previously (Meyerowitz lab protocols at http://web.archive.org/web/20030830084603/www.its.caltech.edu/ $\sim$ plantlab/protocols/quickdna.html). Briefly, samples were homogenized using a sterile mortar and pestle in $500 \mu \mathrm{l}$ of extraction buffer (100 mM Tris [pH 8], $50 \mathrm{mM}$ EDTA, $500 \mathrm{mM} \mathrm{NaCl}$, and $10 \mathrm{mM} \beta$-mercaptoethanol). The extract was transferred to a $1.5-\mathrm{ml}$ tube and $35 \mu \mathrm{l}$ of $20 \%$ sodium dodecyl sulfate were added before incubating at $65^{\circ} \mathrm{C}$ for $5 \mathrm{~min}$. Following incubation, $130 \mu \mathrm{l}$ of $5 \mathrm{M}$ potassium acetate was added, mixed thoroughly, and incubated on ice for $5 \mathrm{~min}$. The mixture was centrifuged at $15,000 \times g$ for $10 \mathrm{~min}$. The supernatant was recovered and the DNA was precipitated by adding $640 \mu \mathrm{l}$ of isopropyl alcohol and $60 \mu \mathrm{l}$ of $3 \mathrm{M}$ sodium acetate and held at $-20^{\circ} \mathrm{C}$ for $10 \mathrm{~min}$. The DNA was washed by precipitating in $70 \%$ ethanol with centrifugation and resuspended in $40 \mu \mathrm{l}$ of water supplemented with RNAse (Invitrogen, Carlsbad, CA) at $1 \mu \mathrm{g} / \mathrm{ml}$.

For the cPCR amplification, primers LsoTX16/23 (16) were designed to amplify a 383-bp region between the $16 \mathrm{~S}$ and $23 \mathrm{~S}$ rRNA genes. Primer sequences of Lso TX 16/23 F and Lso TX 16/23 R were 5'-AATTTTAGCAAGTTCTAAGGG-3' and 5'GGTACCTCCCATATCGC-3', respectively. Primers for $\beta$-tubulin amplification were F: 5'-TGCCACTCACTTGGTGGAGGG-3' and R: 5'-TCATGTTGCTCTCGGCTTCAGTG-3'. cPCR reactions were prepared with Promega Corp. (Madison, WI) GoTaq Colorless Master Mix according to the manufacturer's recommendations. The cPCR was performed using an Eppendorf Thermocycler (Hamburg, Germany) $\left(95^{\circ} \mathrm{C}\right.$ for $3 \mathrm{~min}$; 40 cycles of $95^{\circ} \mathrm{C}$ for $40 \mathrm{~s}, 58^{\circ} \mathrm{C}$ for $40 \mathrm{~s}$, and $72^{\circ} \mathrm{C}$ for $1 \mathrm{~min}$; and $72^{\circ} \mathrm{C}$ for 10 min). cPCR products were examined by gel electrophoresis and verified as necessary by sequencing. For sequencing, the amplicons were cloned into the Topo TA cloning vector (Invitrogen) and sequenced by the Gene Technology Lab, Texas A\&M University.

Quantitative PCR using SYBR Green methodology. 16S rDNA specific primers $\mathrm{LsoF}$ and $\mathrm{HLBr}$ were used for ' $\mathrm{C} a$. $\mathrm{L}$. solanacearum' (CLs) detection and cytochrome oxidase primers COXf and COXr for the host plant (positive internal control or endogene) as described previously $(8,9)$. Primer sequences of LsoF and HLBr were 5'-CGAGCGCTTATTTTTAATAGGAGC$3^{\prime}$ and 5'-GCGTTATCCCGTAGAAAAAGGTAG-3', respectively. Primer sequences for COXf and $\mathrm{COXr}$ were 5'-GTATGC CACTGCGCATTCCAGA-3', and 5'-GCCAAAACTGCTAAG GGCATTC-3', respectively. The quantitative (q)PCR Mastermix for Power SYBR Green (Applied Biosystems, Foster City, CA) was used according to the manufacturer's instructions. Each reaction contained $30 \mathrm{ng}$ of DNA, $0.25 \mu \mathrm{M}$ each primer, $5 \mu \mathrm{l}$ of SYBR Green Master Mix, and $3 \mu \mathrm{l}$ of water. Reactions were set up in 384-well plates and qPCR was run and analyzed using an ABI 7900HT Fast Thermocycler (Applied Biosystems) according to the manufacturer's recommendations. In order to standardize the amount of pathogen to the amount of plant DNA in the extraction, data were reported as a $\Delta \mathrm{Ct}=\left(\mathrm{Ct}_{\text {mean of } \mathrm{CLs}} 16 \mathrm{~S}\right)-$ $\left(\mathrm{Ct}_{\text {mean of endogene }}\right)$. This standardization process takes into account variability between samples caused by technical error (e.g., variability in efficiency of DNA extraction or pipetting errors), which can contribute to even larger variability following PCR amplification. The PCR amplification efficiencies of both qPCR primers (CLs 16S and COX endogene) were the same in both potato and tomato (nearly 100\%). Data represent the mean from three replicates. A positive control (infected plant DNA extract), a negative control (healthy plant DNA extract), and a water control were included in all experiments. 
Quantification of ' $\mathrm{Ca}$. L. solanacearum' using a standardcurve analysis. Two separate standard curves were established for quantification of ' $\mathrm{Ca}$. L. solanacearum' in potato and tomato, respectively. The cPCR product of the ' $\mathrm{Ca}$. L. solanacearum' $16 \mathrm{~S}$ rDNA region amplified using primers $\mathrm{LsoF}$ and $\mathrm{HLBr}$ was cloned into the Topo TA cloning vector (Invitrogen). This plasmid served as the standard. Following plasmid purification, the concentration of plasmid DNA was quantified (NanoVue Plus Spectrophotometer; GE Healthcare, Pittsburgh) and, from that concentration, gene copy number was calculated. Gene copy number can be determined by knowing the size of the amplified fragment (76 bp) and the size of the vector in which the fragment is cloned $(3,956+$ $76=4,032 \mathrm{bp}$ ). The molar mass of the plasmid can be calculated in Daltons: $(\mathrm{g} / \mathrm{mole})=($ bp size of plasmid + insert $) \times(330 \mathrm{Da} \times 2$ nucleotide/bp), and, from that, the weight of one copy of the plasmid: $(\mathrm{g} / \mathrm{molecule})=(\mathrm{g} / \mathrm{mole}) /$ Avogadro's number $6.02 \times 10^{23}$ molecules/mole. By knowing the concentration of the plasmid that is added to each PCR reaction and the weight of that plasmid, the number of molecules in that reaction can be determined as follows: molecules $/ \mu \mathrm{l}=(\mathrm{g} / \mu \mathrm{l}) /(\mathrm{g} / \mathrm{mol})$. Finally, by using the number of molecules (copies) in $1 \mu \mathrm{l}$ of plasmid solution, a series of dilutions can be made for subsequent amplification, providing the data to generate a standard curve (http://technologyinscience. blogspot.com/2011/05/copy-number-calculation-for-qpcr.html).

For the standard curve, the plasmid was diluted 10-fold starting from $1.5 \times 10^{5}$ to $1.5 \times 10^{1}$ copies in $30 \mathrm{ng}$ of DNA extracted from leaf petiole samples (as above) from a healthy plant (11). Closer-interval dilutions were made in the range between $1.5 \times$ $10^{3}$ and $1.5 \times 10^{2}$. qPCR was performed as above. Data were plotted as $\Delta \mathrm{Ct}$ versus the number of ' $\mathrm{Ca}$. L. solanacearum' copies per $30 \mathrm{ng}$ of DNA extracted from plants, and this relationship served as the standard curve (Fig. 1). As above, in order to standardize the amount of pathogen to the amount of plant DNA in the extraction, data were reported as a $\Delta \mathrm{Ct}=\left(\mathrm{Ct}_{\text {mean of CLs 16S }}\right)-$ $\left(\mathrm{Ct}_{\text {mean of endogene }}\right)$. The copy number in each sample was estimated by comparing $\Delta \mathrm{Ct}$ values of each sample to the standard curves.

Three copies of the 16S rRNA genes (qPCR target) were identified using Blastn (National Center for Biotechnology Information) by comparing the region amplified by the primers LsoF and $\mathrm{HLBr}$ to the ' $C a$. L. solanacearum' genome. Detection limits were calculated as ' $C a$. L. solanacearum' genome units (GU) per nanogram of plant DNA (11) (e.g., number of copies [copies of $16 \mathrm{~S}$ rRNA genes per nanogram of DNA extracted from plants]/3 [3 copies/GU]). Data represent the means of three or two (close interval samples) replicates \pm standard deviation.

\section{RESULTS}

Translocation in tomato. As determined by cPCR, after 1 week IAP, ' $C a$. L. solanacearum' could not be detected in any of the leaf petiole samples, even the infested leaf petiole (Table 1). By week four, ' $\mathrm{Ca}$. L. solanacearum' was detected in all of the plants infested with ' $C a$. L. solanacearum'-infected C2 psyllids, either just in the upper tier leaves or in all tiers, indicating that 1 week (the interval the infested leaf remained on the plant) was sufficient time for inoculation by the insect and subsequent translocation of ' $C a$. L. solanacearum' out of the inoculated leaf to the rest of the plant (Supplemental Figure 1; Table 1). By week five, ' $\mathrm{Ca}$. L. solanacearum' could be detected in all upper- and middle-tier leaf petiole samples from the tomato plants treated with ' $\mathrm{Ca}$. L. solanacearum'-infected insects (Table 1). ' $\mathrm{Ca}$. L. solanacearum' was never detected on the plants treated with insects from the 'Ca. L. solanacearum'-uninfected C1 colony (data not shown). By week eight, the upper leaves of infected plants showed symptoms of ZC (curling and yellowing). Interestingly, by the time the infected plants showed symptoms on the upper leaves, all plant tiers were 'Ca. L. solanacearum' positive by PCR and qPCR (Table 1). The uninfected plant showed no symptoms (data not shown). None of the plants showing ZC symptoms died over the 8-week period. qPCR improved detection over cPCR, especially at earlier time points; overall, the qPCR data supported our cPCR data.

Translocation in potato. Compared with tomato, $\mathrm{cPCR}$ detection in potato was highly variable. Only a few generalities can be drawn from these data. First, as observed in tomato, ' $\mathrm{Ca}$. L. solanacearum' could not be detected using cPCR after 1 week of insect feeding in any of the leaf petiole samples, although we detected the pathogen in one upper-tier sample using qPCR (Tables 2 and 3). However, when the insects were given a 21-day IAP, ' $C a$. L. solanacearum' was detected via cPCR in the infested leaf (data not shown). Second, as observed in tomato, 1 week was sufficient time for inoculation by the insect and subsequent translocation of ' $C a$. L. solanacearum' out of the inoculated leaf to the rest of the plant. Third, in both susceptible and potentially tolerant cultivars, ' $C a$. L. solanacearum' was first detected via cPCR 3 weeks after infestation and then, most consistently, in the upper-tier leaf petiole samples (but could be found in all samples on some plants). In subsequent weeks, the pathogen continued to be detected via cPCR and qPCR in all parts of the plant but not consistently (e.g., in some weeks, a leaf sample in a particular tier would be positive and, in other weeks, a sample from a different leaf in the same tier would be negative). Fourth, the pathogen also

\section{A Standard Curve for Potato}

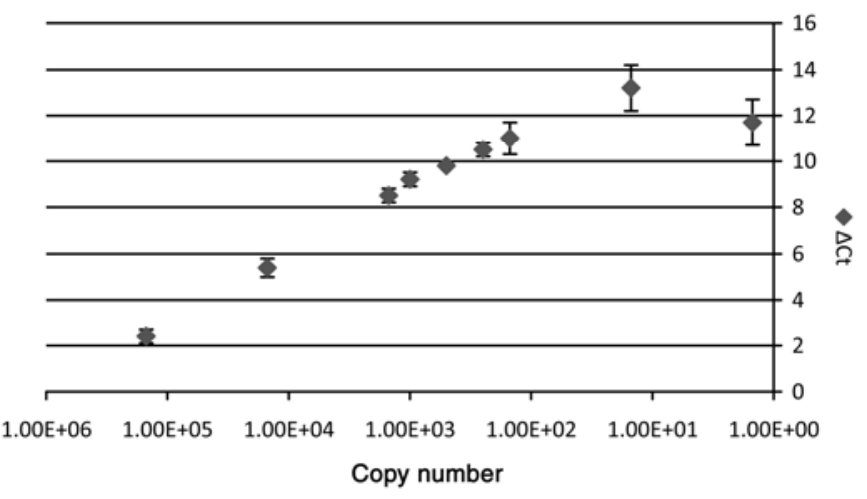

\section{B Standard Curve for Tomato}

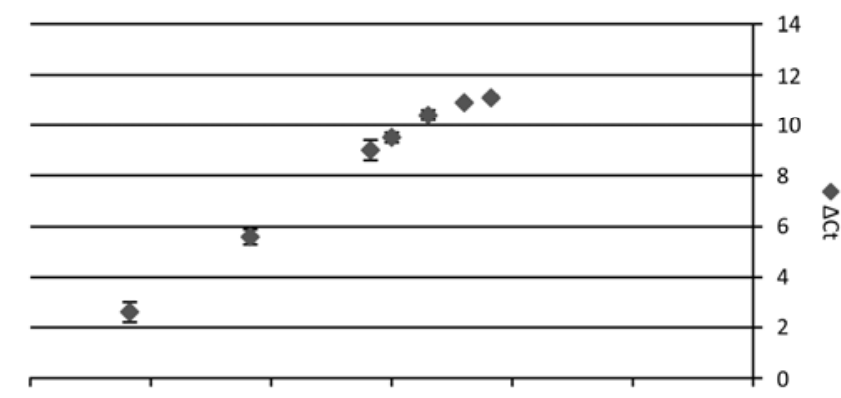

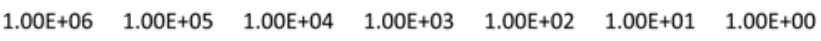

Copy number

Fig. 1. Standard curves based on the relationship between $\Delta \mathrm{Ct}$ (y-axis) and copy number (x-axis: gene copies [logarithmic scale] per $30 \mathrm{ng}$ of DNA). Two separate standards curve were established for quantification of 'Candidatus Liberibacter solanacearum' in $\mathbf{A}$, potato and $\mathbf{B}$, tomato (data given in Supplementary Table 1). The polymerase chain reaction product of the ' $\mathrm{Ca}$. L. solanacearum' 16S rDNA region amplified using primers LsoF and $\mathrm{HLBr}$ was cloned into a plasmid and quantified and, from that, gene copy number was calculated. For the standard curve, the plasmid was diluted 10-fold, covering 1.5 to $1.5 \times 10^{5}$ copies per $30 \mathrm{ng}$ of DNA extracted from plants. Closer interval sampling was done between $1.5 \times 10^{3}$ and $1.5 \times 10^{2}$. Data represent the means of two (close-interval samples) or three replicates $\times$ standard deviation. Data between $1.5 \times 10^{5}$ and $1.5 \times 10^{1}$ are within the linear range of the standard curve for potato $\left(r^{2}=0.99\right)$ and between $1.5 \times 10^{5}$ and $1.5 \times 10^{2}$ for tomato $\left(r^{2}=0.99\right)$. 
could be detected within leaves on noninfested second stems connected via the tuber. The pathogen was first detected in some second stems by week three with qPCR and week four with cPCR and was detected in all second stems with cPCR by week five (Tables 4 and 5). The pathogen was not detected in second stems that had been physically separated at planting from the infested stem but remained in the same pot or in second stems of plants that had not been infected (data not shown). As for tomato, qPCR data were in agreement with cPCR and, in some replicates, qPCR detected the pathogen more reliably than $\mathrm{CPCR}$.

The timing and rate of disease symptom development also was variable. The first ZC symptom (purpling of upper leaves) was observed at 3 to 4 weeks after infestation on the susceptible cultivars of potato (Russet Norkotah and Atlantic) at approximately the same time we could detect the pathogen (Supplemental Figure 2; Tables 2 and 3 ). In contrast, the symptoms developed later (5 to 6 weeks) in the infested stems of potentially tolerant NY138 and BTX1749-1W/Y. Progression to mortality occurred in $\approx 3$ to 5 weeks. Disease symptoms were first observed in the second stem $\approx 1$ to 3 weeks after we detected the pathogen and typically progressed at the same rate (Tables 4 and 5).

qPCR results. ' $C a$. L. solanacearum' detection limits in tomato and potato were estimated separately by the standard curve quantification method (Fig. 1). $\Delta \mathrm{Ct}$ values for samples with 250 copies of the ' $\mathrm{Ca}$. L. solanacearum' $16 \mathrm{~S}$ rDNA target $\left(\Delta \mathrm{Ct}_{250}\right)$ were within the linear range of the standard curve for potato and tomato and were significantly different from the $\Delta \mathrm{Ct}$ for healthy potato and tomato, respectively $\left(\Delta \mathrm{Ct}_{250 \text { copy } / 30 \mathrm{ng} \text { of potato }}=10.5 \pm 0.3\right.$ compared with $\Delta \mathrm{Ct}_{0 \text { copy/30ng of potato }}=12.5 \pm 1.3$ and $\Delta \mathrm{Ct}_{250 \text { copy/30 } \mathrm{ng} \text { of tomato }}=$ 10.9 compared with $\Delta \mathrm{Ct}_{0 \text { copy } / 30}$ ng of tomato $\left.=12.1 \pm 0.9\right)$. Using $\Delta \mathrm{Ct}_{250 \text { copy/30 ng }}$ as our detection limit, we calculated copy number to be $\approx 8$ copies/ng of DNA extracted from plants, which is $\approx 3$ $\mathrm{GU} / \mathrm{ng}$ of plant DNA extract.

Using data from the standard curves, we selected $\Delta \mathrm{Ct} \leq 10.5$ for potato and $\Delta \mathrm{Ct} \leq 10.9$ for tomato as the range of $\Delta \mathrm{Ct}$ values that can be reliably differentiated from $\Delta \mathrm{Ct}$ of healthy tomato and potato samples (i.e., a qPCR-positive result) (Tables 1, 3, and 5). The amplification of product using the $16 \mathrm{~S}$ rDNA ' $\mathrm{Ca}$. L. solanacearum' target in the healthy potato and tomato samples suggests sequence overlap with the plant genomes, probably with plant chloroplast DNA, as observed previously (15). Although not a concern in previous studies using these qPCR primers $(8,9)$, overlap with other endophytes also is possible because a small number of endophytes have been identified from healthy potato (15).

\section{DISCUSSION}

Understanding the direction and rate of translocation of ' $\mathrm{Ca}$. L. solanacearum' in plants is critical for knowing how and when to sample plants in the field for early detection. Furthermore, comparison of translocation patterns between susceptible and potentially tolerant cultivars may contribute to a better understanding of disease tolerance mechanisms and when and in what tissues to look for key interactions between the microbe and plant. Although little is known about the translocation patterns of ' $\mathrm{Ca}$. L.

TABLE 1. Time course of symptoms and pathogen detection in newly developing upper-tier leaves, recently expanded middle-tier leaves, and mature lower-tier leaves of tomato

\begin{tabular}{|c|c|c|c|c|c|c|c|}
\hline \multirow[b]{2}{*}{ Time $(\mathrm{wpi})^{\mathrm{a}}$} & \multirow{2}{*}{$\begin{array}{c}\text { Symptoms } \\
\text { Entire plant }\end{array}$} & \multicolumn{3}{|c|}{ PCR detection of $\mathrm{CLs}^{\mathrm{b}}$} & \multicolumn{3}{|c|}{ qPCR detection of CLs ${ }^{c}$} \\
\hline & & Upper tier & Middle tier & Lower tier & Upper tier & Middle tier & Lower tier \\
\hline Week 1 & - & - & $-\mathrm{d}$ & - & nd & nd & nd \\
\hline Week 2 & - & - & - & - & $11.1,11.1(0 / 2)$ & $10.3,11.5(1 / 2)$ & $9.6,14.2(1 / 2)$ \\
\hline Week 4 & - & + & $\pm(3 / 5)$ & $\pm(2 / 5)$ & $5.9,7.1(2 / 2)$ & $7.8,8.3(2 / 2)$ & $9.7,11.9(1 / 2)$ \\
\hline Week 5 & - & + & + & $\pm(2 / 5)$ & $0.3,3.9(2 / 2)$ & $1.9,5.4(2 / 2)$ & $6.0,11(1 / 2)$ \\
\hline Week 6 & - & + & + & $\pm(2 / 5)$ & $1.3,4.1(2 / 2)$ & $4.1,7.8(2 / 2)$ & $6.1,9.9(2 / 2)$ \\
\hline
\end{tabular}

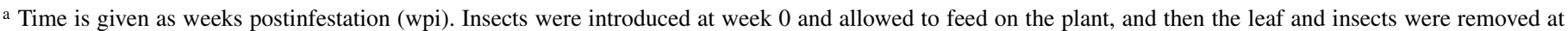
week 1 .

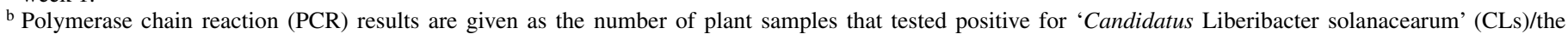
number plants tested; $-=$ no plants tested positive, $+=$ all plants tested positive, and $\pm=$ fraction of the plants tested positive.

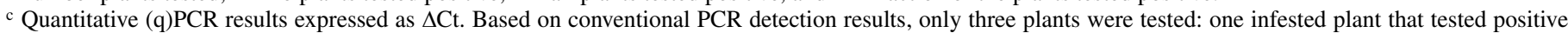
for all samples, one infested plant that had the most negative PCR results, and the plant infested with the ' $\mathrm{Ca}$. L. solanacearum'-uninfected (C1) psyllid population. Data are the mean of three replicates. qPCR values for the tomato infested with psyllids from the $\mathrm{C} 1$ populations were all $>11.2$. According to the standard curve, $\Delta \mathrm{Ct}>10.9$ may not be reliably different from the $\Delta \mathrm{C}$ values of samples from healthy plants. Values of $\Delta \mathrm{Ct} \leq 10.9$ are considered ' $\mathrm{Ca}$. L. solanacearum' positive. $\Delta \mathrm{Ct}$ and the number that tested positive for ' $\mathrm{Ca}$. L. solanacearum' (CLs)/the number plants tested are reported only for the plants infested with ' $C a$. L. solanacearum'-infected psyllids. Some samples were not done (nd).

$\mathrm{d}$ The middle leaf sample from week 1 was the leaf on which insects were allowed to feed within the clip cages.

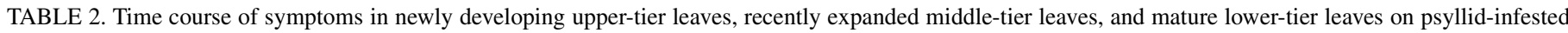
potato stems ${ }^{\mathrm{a}}$

\begin{tabular}{|c|c|c|c|c|}
\hline \multirow[b]{2}{*}{ Time $^{b}$} & \multicolumn{4}{|c|}{ Symptoms for each cultivar } \\
\hline & Russet Norkotah & Atlantic & NY138 & BTX1749-1W/Y \\
\hline Week 1 & Healthy & Healthy & Healthy & Healthy \\
\hline Week 2 & Healthy & Healthy & Healthy & Healthy \\
\hline Week 3 & Healthy & ZC symptoms & Healthy & Healthy \\
\hline Week 4 & ZC symptoms & ZC symptoms & Healthy & Healthy \\
\hline Week 5 & ZC symptoms & ZC symptoms & Healthy & Healthy \\
\hline Week 6 & Moribund & $\mathrm{ZC}$ symptoms & ZC symptoms & ZC symptoms \\
\hline Week 7 & Dead & ZC symptoms & ZC symptoms & ZC symptoms \\
\hline Week 8 & Dead & Very sick & Dead & Very sick \\
\hline
\end{tabular}

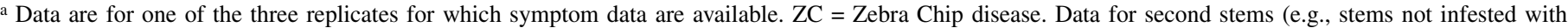
psyllids but connected via the tuber to the infested stem) are given in Table 4.

$\mathrm{b}$ Time is given as weeks postinfestation. Insects were introduced at week 0 and allowed to feed on the plant, and then the leaf and insects were removed at week 1. 
solanacearum' in infected plants, translocation patterns of phloemlimited viruses and some phytoplasmas are well documented. To systematically invade a plant, viruses must be able to move between cells via the plasmodesmata to the vascular tissue. Reported rates of short-distance spread are on the order of $1 \mathrm{~mm} /$ day; thus, movement from the site of infection on a leaf to the leaf's petiole may take 2 to 5 days (17). Once the virus enters the phloem, longdistance spread may proceed rapidly, and the direction of movement typically follows source-to-sink patterns of carbohydrate translocation in the plant $(4,7,12)$. For example, Samuel (17) demonstrated that, after entering the phloem of tomato plants, TMV was first directed to the roots where the virus was detected 4 days postinfection and, subsequently, to the top of the plant to the newly developing leaves where virus was detected 8 days postinfection. From there, the virus spread systemically throughout the plant and could be detected in mature leaves 25 days postinfection. In contrast, phytoplasmas, which are restricted to the phloem, spread throughout the plant by moving through the pores of the sieve plates and do not necessarily move from source to sink. They may be found more commonly in symptomatic source tissues compared with sink tissues (2). The titers of both virus and phytoplasma were shown to vary substantially in infected tissue over time $(2,12)$.

We hypothesized that, if ' $C a$. L. solanacearum' were being translocated in the phloem in accordance with the source-to-sink metabolite stream, the direction and rate of movement might be similar to translocation patterns of viruses. Accordingly, newly differentiated sink leaves that import photoassimilates would be infected sooner than fully developed source leaves, and pathogen detection away from the site of infection might require one or more weeks, depending on the tissue sampled. The results demonstrate that rates and direction of translocation of ' $\mathrm{Ca}$. L. solanacearum' in tomato and potato were similar to patterns of virus movement. That ' $\mathrm{Ca}$. L. solanacearum' can move from the site of infection into the main stem in as little as 7 days was demonstrated by the fact that all plants were infected, despite the infested leaves being removed after a 1-week IAP. In tomato, detection of ' $\mathrm{Ca}$. L. solanacearum' in leaf petiole samples did not occur until 1 to 3 weeks after infestation and then the pathogen often was detected first in the upper leaf samples, which suggested that the newly differentiated leaves were the strongest or nearest sink for carbohydrates produced from leaves located on middle-tier branches. Interestingly, we did not detect ZC symptoms until week eight and then starting in the upper leaves. These data suggest that symptomology follows the same pattern as pathogen movement but lags several weeks behind the arrival of the pathogen in that tissue.

As in tomato, the direction of pathogen translocation in potato appears to follow source-to-sink movement of carbohydrates toward the newly differentiating leaves. In potato, ' $\mathrm{Ca}$. L. solana-

TABLE 3. Pathogen detection in newly developing upper-tier leaves, recently expanded middle-tier leaves, and mature lower-tier leaves on psyllid-infested potato stems ${ }^{\mathrm{a}}$

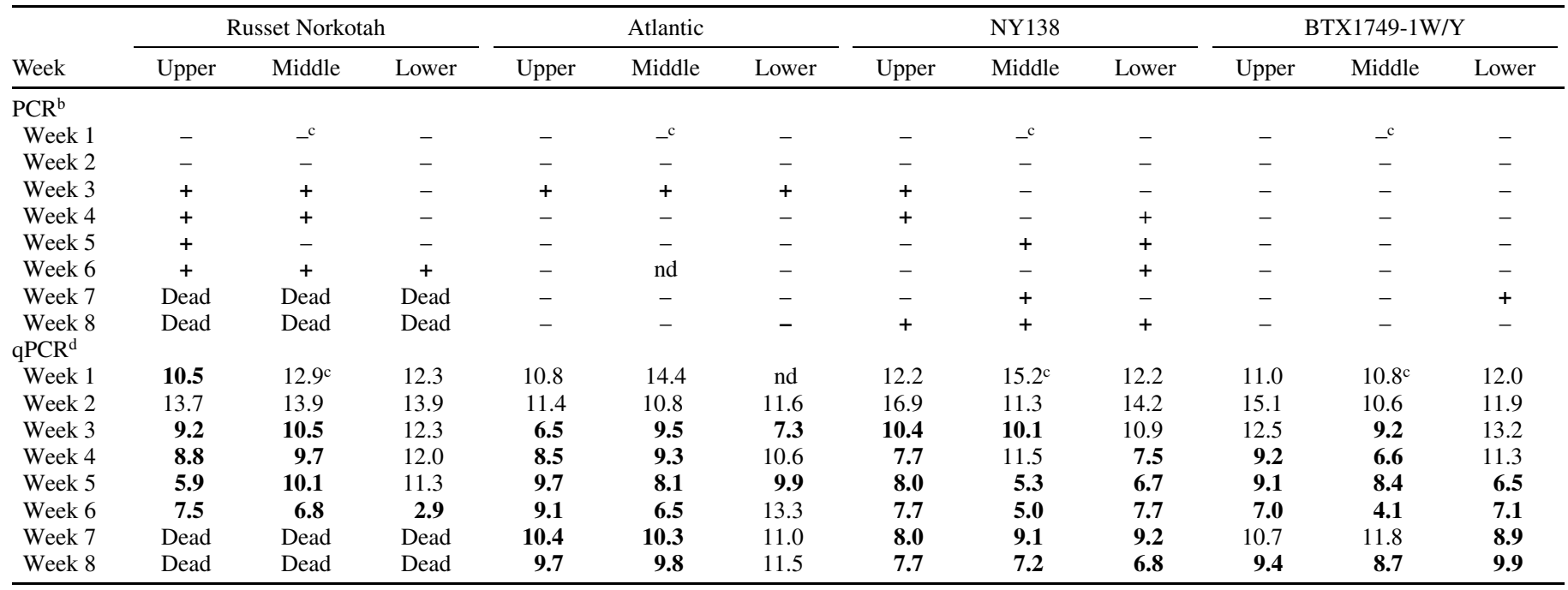

a Data are for one of the two replicates for which conventional polymerase chain reaction (PCR) and quantitative (q)PCR data are available. Some plant samples were not done (nd). Data for second stems (e.g., stems not infested with psyllids but connected via the tuber to the infested stem) are given in Table 5.

b PCR results are given as $-=$ no detection and + (in bold $)=$ detection of 'Candidatus Liberibacter solanacearum'.

c The middle leaf sample from week 1 was the leaf on which insects were allowed to feed within the clip cages.

${ }^{\mathrm{d}} \mathrm{qPCR}$ results as a $\Delta \mathrm{Ct}$. Data from the standard curve suggest that $\Delta \mathrm{Ct}>10.5$ may not be reliably different from the $\Delta \mathrm{Ct}$ value obtained from samples from healthy plants. Values of $\Delta \mathrm{Ct} \leq 10.5$ are considered ' $\mathrm{Ca}$. L. solanacearum' positive and are shown in bold.

TABLE 4. Time course of symptoms in newly developing upper-tier leaves, recently expanded middle-tier leaves, and mature lower-tier leaves on untreated second stems of potato plants described in Table $2^{\mathrm{a}}$

\begin{tabular}{llllc}
\hline Time $^{\mathrm{b}}$ & Russet Norkotah & Atlantic & NY138 & BTX1749-1W/Yc \\
\hline Week 1 & Healthy & Healthy & Healthy & Healthy \\
Week 2 & Healthy & Healthy & Healthy & Healthy \\
Week 3 & Healthy & Healthy & Healthy & Healthy \\
Week 4 & Healthy & Healthy & Healthy & Healthy \\
Week 5 & Healthy & Healthy & Healthy & Healthy \\
Week 6 & ZC symptoms & ZC symptoms & ZC symptoms \\
Week 7 & ZC symptoms & ZC symptoms & ZC symptoms \\
Week 8 & Dead & ZC symptoms & Healthy & ZC symptoms \\
\hline
\end{tabular}

${ }^{\text {a }}$ Second stems were not infested with psyllids but were connected via the tuber to the infested stem (Table 2). ZC = Zebra Chip disease.

${ }^{\mathrm{b}}$ Time is given as weeks postinfestation. Insects were introduced at week 0 and allowed to feed on the plant, and then the leaf and insects were removed at week 1.

c BTX1749-1W/Y second stem was very small and did not have tiers of branches. We sampled only upper leaves on this stem. 
cearum' was detected 2 weeks after infestation and then often in the upper or middle leaves of the infested stem. Pathogen movement from an infested leaf on one stem to leaves on a second, noninfested stem also was observed but only if the stems were physically connected via the tuber. We recognize that the pattern of movement observed may be defined by the developmental stage of the potato (e.g., flow of carbohydrates may be both upward and downward to provision the newly developing leaves and tubers, respectively). Translocation of ' $\mathrm{Ca}$. L. solanacearum' to the lower part of the potato plant is supported by previous work $(8,19)$ demonstrating higher detection by both cPCR and qPCR in roots and stolons than in aboveground plant parts. In this experiment, because we were unable to sample roots or stolons due to the destructive nature of sampling and no tubers developed before plant death, we have no measurement of translocation to underground structures.

Interestingly, although rates (time to detection of the pathogen) and extent (virtually all plant tissues sampled were positive by week eight) of pathogen translocation were similar between species and between potentially tolerant and susceptible potato cultivars, the rates of symptom development were not similar. Symptoms developed much later and were less severe in the single tomato cultivar tested than those observed on potato. Qualitative comparison of symptom development among potato cultivars suggested earlier onset and greater severity of symptoms in both susceptible Atlantic and Russet Norkotah cultivars compared with NY138 and BTX1749-1W/Y. These findings are interesting because they suggest that differences in symptom development between tomato and potato and between susceptible and potentially tolerant potato cultivars are more likely due to pathogenhost interactions or host response than simply to presence of the pathogen in a tissue.

Vector-host and vector-pathogen interactions also may contribute to differences in disease progress due to variability in insect feeding and inoculation success on different hosts and ' $\mathrm{Ca}$. L. solanacearum' titer within the psyllids. Vector preference and behavior have been hypothesized to contribute to tolerance or avoidance of ZC by both NY138 and BTX1749-1W/Y in field trials. This hypothesis is supported by unpublished observations available online (http://zebrachip.tamu.edu/files/2011/01/ Butler_2_ZCC2010.pdf) where, in growth chamber transmission trials, they found that psyllids spent a significantly greater amount of time off NY138 than Russet Norkotah (BTX1749-1W/Y and Atlantic were intermediate); when on the plant, psyllids spent a shorter amount of time feeding and a greater amount of time resting on NY138 and BTX1749-1W/Y than they did on Russet Norkotah (Atlantic was intermediate). In the present study, we removed insect preference by forcing the psyllids to feed on a particular leaf. We did not specifically test the effects of insect number, behavior, or bacterial titer in the insect on reliability of detection, largely because the relationships between these factors and the number of bacteria transmitted to plants are unknown. In this study, given that $\approx 70 \%$ of the insects were harboring ' $\mathrm{Ca}$. L. solanacearum' at a level detectable by PCR, we used two insects and a 1-week IAP to inoculate the plants. These conditions were sufficient for $100 \%$ infection of the 5 tomato and 12 potato plant replicates. Previously, it was reported that using a single insect and a $24 \mathrm{~h}$ IAP was sufficient for $100 \%$ infection of the five potato plant replicates tested (https://www.fritolayag.com/public/zc/ Munyaneza_Joe_ZC2009_1.pdf). As in this study, the titer of the bacteria in the insects, the number of feeding events, and number of bacteria transmitted to the plants were unknown. Our study focuses on reliability of pathogen detection under low insect pressure (i.e., we used a small number of insects $[n=2]$ and a relatively short IAP [1 week]).

In this study, as in previous studies $(8,19)$, cPCR was somewhat unreliable relative to $\mathrm{qPCR}$ in detecting the pathogen in potato, even in symptomatic plants. For example, during some weeks, a leaf sample in a particular tier (upper, middle, or lower) would be positive and, in other weeks, a sample from a different leaf in the same tier would be negative. There are several possible explanations for this. The first may be related to the vascular connectivity of the leaves sampled relative to the infested leaf. Source leaves preferentially supply sinks with which they have direct vascular connections with vertical rows of leaves, forming an orthostichy. Although pruning via leaf sampling can facilitate alternative translocation pathways, it may take time for cross-transfer of photosynthates to sink leaves outside the othostichy to occur.

TABLE 5. Pathogen detection in newly developing upper-tier leaves, recently expanded middle-tier leaves, and mature lower-tier leaves on untreated second stems of potato plants described in Table $3^{\mathrm{a}}$

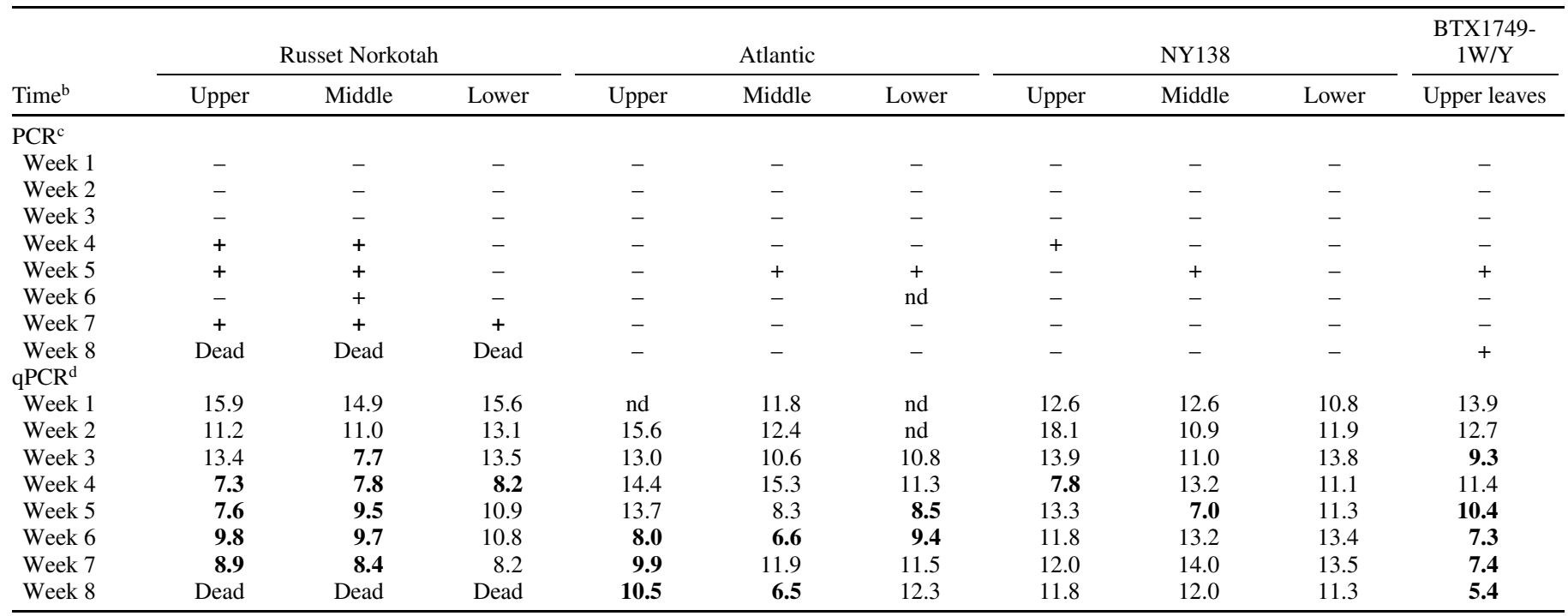

${ }^{a}$ Conventional polymerase chain reaction (PCR) and quantitative (q)PCR data are given. Second stems were not infested with psyllids but were connected via the tuber to the infested stem (Table 3). Some plant samples were not done (nd).

${ }^{\mathrm{b}}$ Time is given as weeks postinfestation. Insects were introduced at week 0 and allowed to feed on the plant, and then the leaf and insects were removed at week 1.

' PCR results are given as: $-=$ no detection, + (in bold) $=$ detection of 'Candidatus Liberibacter solanacearum'.

${ }^{\mathrm{d}} \mathrm{qPCR}$ results as a $\Delta \mathrm{Ct}$. Data from the standard curve suggest that $\Delta \mathrm{Ct}>10.5$ may not be reliably different from the $\Delta \mathrm{Ct}$ value obtained from samples from healthy plants. Values of $\Delta \mathrm{Ct} \leq 10.5$ are considered ' $\mathrm{Ca}$. L. solanacearum' positive and are shown in bold. 
Thus, movement of the pathogen to a leaf outside the othostichy of the infested leaf might be delayed relative to one inside the othostichy, a consideration for field sampling, too. Despite the fact that we undoubtedly sampled leaves outside the orthostichy of the infested leaf (given the number of leaves sampled), it is interesting to note that detection of the pathogen in sampled leaves was high, which suggested that the pathogen was being translocated throughout the plant. Second, the bacterial titer in both tomato and potato was very low and, hence, may be outside the detection range for cPCR. qPCR data demonstrated that, even in symptomatic plants, $\Delta \mathrm{Ct}$ values in leaf petiole samples often were $\geq \Delta \mathrm{Ct}_{1,000}$ values in our standard curves. These data indicated that the titer of ' $\mathrm{Ca}$. L. solanacearum' in those leaf samples was on the order of 33 copies/ng of DNA extracted from plants, which is $\approx 11 \mathrm{GU} / \mathrm{ng}$ of DNA. At final stages of disease development, qPCR indicated that ' $C a$. L. solanacearum' titers reached $\approx 1.5 \times$ $10^{3} \mathrm{GU} / \mathrm{ng}$ of DNA. For comparison, the concentration of the phytoplasma 'Candidatus Phytoplasma pruorum' in infected apricot trees ranged from $1.55 \times 10^{2}$ to $6.18 \times 10^{3} \mathrm{GU} / \mathrm{ng}$ of DNA (11).

In this work, we utilized a standard curve methodology for the quantification of bacteria in plants, as described previously $(6,11)$. We found quantification of the pathogen using GU per nanogram of DNA extracted from plants more useful than previously reported methods that standardize detection levels to plant fresh weight $(6,8)$ or to a specific amount of the DNA extraction volume (19), without accounting for possible variability in DNA extraction. We suggest standardizing to an amount of DNA after extraction facilitates comparisons between studies.

Based on the results, we recommend that plant sampling for detection of the pathogen include newly developing leaves, because this is where ' $\mathrm{Ca}$. L. solanacearum' can be detected first in aboveground tissues. Furthermore, sampling protocols should consider that the pathogen may not be detectable via conventional or quantitative PCR until 3 weeks after infestation, especially if insect pressure is low. We believe that improved PCR detection methodologies combined with a better understanding of what plant tissues to sample for a phloem-limited bacterium will significantly improve early detection of ' $\mathrm{Ca}$. L. solanacearum'.

\section{ACKNOWLEDGMENTS}

This work was funded, in part, by the Texas AgriLife Research Zebra Chip Disease Program. We thank C. Miller, D. Scheuring, P. Nachappa, C. Seeve, H. Scholthof, V. Alvarado, C. Rush, and D. Henne for their contributions of materials or ideas to the work; and S. Zachry and D. Juarez, undergraduate research assistants, for diligence in sample preparation and PCR.

\section{LITERATURE CITED}

1. Brown, J. K., Rehman, M., Rogan, D., Martin, R. R., and Idris, A. M. 2010. First report of 'Candidatus Liberibacter psyllaurous' (syn. 'Ca. L. solanacearum') associated with the 'tomato vein-greening' and 'tomato psyllid yellows' diseases in commercial greenhouses in Arizona. Plant Dis. 94:376.
2. Christensen, N. M., Nicolaisen, M., Hansen, M. and Schulz, A. 2004. Distribution of phytoplasmas in infected plants as revealed by real-time PCR and bioimaging. Mol. Plant-Microbe Interact. 17:1175-1184.

3. Crosslin, J. M., and Munyaneza, J. E. 2009. Evidence that the zebra chip disease and the putative causal agent can be maintained in potatoes by grafting and in vitro. Am. J. Pot. Res. 86:183-187.

4. Gosalvez-Bernal, B., Genoves, A., Navarro, J. A., Pallas V., and SanchesPina, M. A. 2008. Distribution and pathway for phloem-dependent movement of Melon necrotic spot virus in melon plants. Mol. Plant Pathol. 9:447-461.

5. Hansen, A. K., Trumble, J. T., Stouthamer, R., and Paine, T. D. 2008. A new huanglongbing species, 'Candidatus Liberibacter psyllaurous,' found to infect tomato and potato, is vectored by the psyllid Bactericera cockerelli (Sulc). Appl. Environ. Microbiol. 74:5862-5865.

6. Jarausch, W., Peccerella, T., Schwind, N., Jarausch, B., and Krczal, G. 2004. Establishment of a quantitative real-time PCR assay for quantification of apple proliferation phytoplasma in plants and insects. Acta Hortic. 657:415-420.

7. Leisner, R. M., Turgeon, R., and Howell, S. H. 1992. Long distance movement of cauliflower mosaic virus in infected turnip plants. Mol. Plant-Microbe Interact. 5:41-47.

8. Li, W., Abad, J. A., French-Monar, R. D., Rascoe, J., Wen, A., Gudmestad, N. C., Secor, G. A., Lee, I.-M., Duan, Y., and Levy, L. 2009. Multiplex real-time PCR for detection, identification and quantification of 'Candidatus Liberibacter solanacearum' in potato plants with zebra ship. J. Microbiol. Methods 78:59-65.

9. Li, W., Hartung, J. S., and Levy, L. 2006. Quantitative real-time PCR for detection and identification of 'Candidatus Liberibacter species' associated with citrus huanglongbing. J. Microbiol. Methods 66:104-115.

10. Liefting, L. W., Sutherland, P. W., Ward, L. I., Paice, K. L., Weir, B. S., and Clover, G. R. G. 2009. A new 'Candidatus Liberibacter' species associated with diseases of solanaceous crops. Plant Dis. 93:208-214.

11. Martini, M., Lol, N., Ermacora, P, Carraro, L., and Pastore, M. 2007. A real-time PCR method for detection and quantification of 'Candidatus Phytoplasma prunorum' in its natural hosts. Bull. Insectol. 60:251-252.

12. Mas, P., and Pallas V. 1996. Long-distance movement of cherry leaf roll virus in infected tobacco plants. J. Gen. Virol. 77:531-540.

13. Miller, C., Scheuring, D., and Koym, J. 2010. Texas Potato Breeding Report. Texas AgriLife Research/Department of Horticultural Sciences, Texas A\&M University, College Station and Lubbock.

14. Miller, J. C., Jr., Koym, J. W., Scheuring, D. C., and Miller, J. P. 2010. Southwest Regional Potato Variety Trial Report 2009. Texas AgriLife Research, College Station and Lubbock.

15. Nachappa, P, Levy, J., Pierson, E., and Tamborindeguy, C. 2011. Diversity of endosymbionts in Candidatus Liberibacter solanacearum-uninfected and infected populations of potato psyllid, Bactericera cockerelli, vector of zebra chip disease of potato. Curr. Microbiol. 62:1510-1520.

16. Ravindran, A., Levy, J., Pierson, E., and Gross, D. 2011. Development of primers for improved PCR detection of the potato zebra chip pathogen, 'Candidatus Liberibacter solanacearum'. Plant Dis. DOI: 10.1094/PDIS05-11-0386.

17. Samuel, G. 1934. The movement of tobacco mosaic virus within the plant. Ann. Appl. Biol. 21:90-111.

18. Secor, G. A., Rivera, V. V., Abad, J. A., Lee, I.-M., Clover, G. R. G., Liefting, L. W., Li, X., and De Boer, S. H. 2009. Association of 'Candidatus Liberibacter solanacearum' with zebra chip disease of potato established by graft and psyllid transmission, electron microscopy, and PCR. Plant Dis. 93:574-583.

19. Wen, A., Mallik, I., Alvarado, V. Y., Pasche, J. S., Wang, X., Li, W., Levy, L., Lin, H., Scholthof, H. B., Mirkov, T. E., Rush, C. M., and Gudmetad, N. C. 2009. Detection, distribution, and genetic variability of 'Candidatus Liberibacter' species associated with zebra complex disease of potato in North America. Plant Dis. 93:1102-1115. 